Abstracta Iranica Iranica

Revue bibliographique pour le domaine irano-aryen

Volume 30 | 2010

Comptes rendus des publications de 2007

\title{
Sufism and Theology. Edinburgh, Edinburgh University Press, 2007, 201 p.
}

Ève Feuillebois-Piérunek

\section{Q OpenEdition}

1 Journals

Édition électronique

URL : http://journals.openedition.org/abstractairanica/37930

DOI : 10.4000/abstractairanica.37930

ISSN : 1961-960X

\section{Éditeur :}

CNRS (UMR 7528 Mondes iraniens et indiens), Éditions de l'IFRI

\section{Édition imprimée}

Date de publication : 8 avril 2010

ISSN : 0240-8910

\section{Référence électronique}

Ève Feuillebois-Piérunek, «Sufism and Theology. Edinburgh, Edinburgh University Press, 2007, 201 p. », Abstracta Iranica [En ligne], Volume 30 | 2010, document 233, mis en ligne le 08 avril 2010, consulté le 26 septembre 2020. URL : http://journals.openedition.org/abstractairanica/37930 ; DOI : https:// doi.org/10.4000/abstractairanica.37930

Ce document a été généré automatiquement le 26 septembre 2020.

Tous droits réservés 


\title{
Sufism and Theology. Edinburgh, Edinburgh University Press, 2007, $201 \mathrm{p}$.
}

\author{
Ève Feuillebois-Piérunek
}

1 Les dix articles étudient les rapports complexes entre le soufisme et la théologie: comment les soufis ont approché les traditions théologiques, ou pratiqué la théologie, et comment les théologiens se sont positionnés par rapport à différents aspects du soufisme.

2 Le livre est composé de deux parties. La première est consacrée aux "théologies mystiques". Annabel Keeler signe un article intitulé "Mystical Theology and the Traditionalist Hermeneutics of Maybudî's Kashf al-Asrâr ». Influencé par Anșārī et opposé à l'ash'arisme, Maybudī (XII ${ }^{\mathrm{e}}$ s.) illustre les affinités entre le soufisme et le courant théologique traditionnaliste, tous deux suspicieux à l'égard de la théorisation métaphysique.

Dans «The All-Comprehensive Circle (al-Ihâta): Soul, Intellect, and the Oneness of Existence in the Doctrine of Ibn Sab'în ", Vincent J. Cornell montre qu'Ibn Sab'în (XIII s.) ne cherche pas à islamiser à tout prix son mysticisme intellectuel, contrairement à Ibn 'Arabī. Il lui attribue par ailleurs la paternité du concept de wah̆dat al-wujūd qu'Ibn 'Arabī lui aurait emprunté.

4 Dans "One Aspect of the Akbarian Turn in Shi'i Theology", Robert Visnevsky s'intéresse à la manière dont des éléments du soufisme ésotérique ont été modifiés et intégrés à la théologie shi'ite du XIV ${ }^{\mathrm{e}} \mathrm{s}$. par Ḥaydar Āmolì à la faveur de sa synthèse des pensées de Najm al-dīn Kubrā et d'Ibn 'Arabī, permettant à l'Homme Parfait d'être identifié à l'Imam.

5 « Sufism and Theology in the Confessions of Sâ'in al-din Turka Isfahânî (d. 830/1437) » de Leonard Lewisohn étudie l'apologie de cet auteur accusé d'hérésie qui défend son orthodoxie théologique sans renier son soufisme, et présente une typologie de sept approches ou traditions en Islam. 
Dans « A Sufi Theology Fit for a Shi'i King: The Gawhar-i Murâd of 'Abd

al-Razzâq Lâhîîi (d. 1072/1661-2) », Sajjad Rizvi examine le sort des communautés soufies et les diverses critiques auxquelles le soufisme fut soumis sous les Safavides. Il montre comment Lāhijjī crée une théologie synthétique soufie-shi'ite à l'usage de šāh 'Abbās II, attiré par un soufisme non institutionnel.

La seconde partie est consacrée aux approches théologiques du soufisme.

Dans "The Mystic and the Sceptic in Fakhr al-dîn al-Râzî », Ayman Shihadeh montre comment l'un des plus grands théologiens musulmans s'est tourné vers le soufisme à la fin de sa vie, en raison du scepticisme qui l'avait envahi concernant la théologie rationnelle et comment il avait été conduit à réévaluer l'importance de la sagesse mystique par rapport à la théologie et à la philosophie, suivant ainsi jusqu'à un certain point les pas de Ġazālī.

«Ibn Taymiyya's Commentary on the Creed of al-Hallâj » de Yahyâ Michot étudie l'acceptabilité du soufisme pour les traditionnalistes. Dans Al-Istiqāma, Ibn Taymiyya commente l'œuvre d'al-Qušayrī. Ce dernier défend la thèse selon laquelle la sagesse soufie, acquise par révélation et vision, serait pleinement compatible avec la théologie ash'arite. Ibn Taymiyya infirme ce jugement, estimant que le soufisme "sobre" (Junayd, ...) est plus proche de la pensée traditionnaliste, alors que certains courants ou doctrines du soufisme (Hallāj) sont hérétiques.

10 Tim Winter, dans «Ibn Kemal (d. 940/1534) and Ibn “Arabî”s Hagiology ", se penche sur la question de l'impact des idées d'Ibn 'Arabī dans l'Anatolie des XIV ${ }^{e}, \mathrm{XV}^{\mathrm{e}}$ et $\mathrm{XVI}^{\mathrm{e}}$ siècles, époque où la pensée du ŠayH al-Akbar fut très en vogue à la fois dans l'establishment sunnite du nouvel empire ottoman et dans le shi'isme populaire messianique des tribus turcomanes. Il décrit les efforts du théologien ottoman Ibn Kemal pour rapprocher Ibn 'Arabī du Kalām et rejeter les adaptations populaires de sa doctrine, dangereuses pour les Ottomans à l'heure de l'émergence des Safavides shi'ites dans la Perse voisine.

Dans « Scriptural Sufism and Scriptural Anti-Sufism: Theology and Mysticism amongst the Shi'i Akhbâriyya ", Robert Gleave démontre que les approches diversifiées du courant shi'ite aHbārī face au soufisme sont dues au fait que le fondateur de ce courant essentiellement juridique, Astarābādī (m. 1626), n'a pas clairement statué sur cette question, laissant une large marge d'interprétation à ses successeurs.

Enfin, dans "Reconciling Sufism with Theology: Abû l-Wafâ al-Taftâzânî and the Construct of 'al-Tasawwuf al-islâmî' in Modern Egypt", Andreas Christman s'intéresse à la période réformiste en Egypte. Le soufisme y fut sévèrement critiqué des points de vue juridique, théologique, moral et socio-politique et fut accusé d'entrer en contradiction avec la lettre et l'esprit de l'islam. Cette situation amena l'émergence d'un mouvement au sein des cercles soufis cultivés, visant à la fois à faire l'apologie du soufisme et à le réformer.

13 L'A., à travers une riche palette de sujets allant de l'herméneutique à la métaphysique en passant par la psychologie, nous éclaire sur les courants intellectuels majeurs en Islam, du XII ${ }^{e}$ s. à la période moderne, du sunnisme au shi'isme, de l'empire ottoman aux Safavides.

Un ensemble excellent qui donne envie d'approfondir la question. 
INDEX

Thèmes : 8 . Soufisme

\section{AUTEURS}

\section{ĖVE FEUILLEBOIS-PIÉRUNEK}

Université Sorbonne Nouvelle-Paris III/Mondes iranien et indien 